\title{
Enhancement of Solubility and Dissolution Rate of Carvedilol by Using Fluidized-bed Granulation Technique.
}

\author{
Dipika Shashikant Pawar*, Rajendra K. Surawase \\ Department of Pharmaceutics, Loknete Dr. J.D. Pawar College of Pharmacy Manur (Kalwan), Nashik, Maharashtra, India. \\ *Corresponding author's E-mail: dipupawar655@gmail.com.
}

Received: 04-09-2020; Revised: 25-10-2020; Accepted: 29-10-2020; Published on: 15-11-2020.

\section{ABSTRACT}

Carvedilol is a non-selective beta- blocker with alpha-1-receptor blocking activity. Carvedilol drug is widely used in treatment of cardiovascular disease. Carvedilol is belonging to BCS Class II drug, It characterized by poor water solubility and high permeability. The main objective of this study is to enhance the solubility and dissolution rate of Carvedilol drug to achieve desired concentration of drug in systemic circulation for achieving the required pharmacological response by using Novel technique i.e., fluidized bed granulation technique by using wide variety of carriers such as PVP K30, Poloxamer 188 as a super disintegrant. The formulation F6 showed Enhance Solubility and Dissolution rate of Carvedilol drug released approximately $95.18 \%$ for $30 \mathrm{~min}$. So, it was selected as the best formulation among all the nine formulations.

Keywords: Carvedilol, Fluidized bed granulation technique, Dissolution, Solubility.

QUICK RESPONSE CODE $\rightarrow$

DOI:

10.47583/ijpsrr.2020.v65i01.027

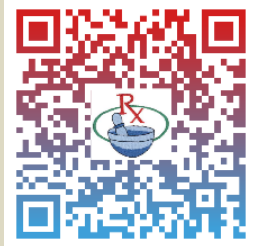

DOI link: http://dx.doi.org/10.47583/ijpsrr.2020.v65i01.027

\section{INTRODUCTION}

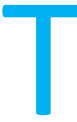

he Drug is administered by the oral route it go through a next process that are dissolution and permeation across the gastrointestinal membrane before they reach in systemic circulation. Number of factors that are affect in bioavailability of the drug, one of the major factor is that solubility and dissolution. Solubility of drug aqueous gastrointestinal fluid is major problem with the most drugs. At least $40 \%$ of newly developed chemical entity tested are drug having poor aqueous solubility this leads to fluctuating the bioavailability Among the various solubility enhancement technique, Solid dispersion is most preferable and effective strategies to enhance the solubility, dissolution rate, and oral bioavailability of poorly aqueous soluble drugs. In solid dispersion method reduction in particle size and an increase in surface area of poorly water-soluble drugs, resulting in enhanced solubility and dissolution rate. The main objective of this study is to enhance the solubility and dissolution rate of Carvedilol drug to achieve desired concentration of drug in systemic circulation for achieving the required pharmacological response by using Novel technique i.e., fluidized bed granulation technique. FBG used in this study over conventional granulation method because instability due to huge ratio of excipients to drug to drug substances. Chemical instability due to drug having greater surface exposure excipients, moisture and manufacturing equipments. Low potency due to manufacturing loss. Variations in content uniformity can cause more problems in low dose drug than high dose.

\section{Fluidized Bed Processor}

In 1953 Dale Wruster invented the coating of tablets by spraying the coating solution on tablets bed stream of warm air suspended in warm air in 1953 this process also known as wruster process. In $1960 \mathrm{Dr}$. Dale Wruster further carried out the granulation of powders.

Fluid bed processing involves coating, granulation, drug layering and drying of particulate material.

\section{Fluidized Bed Granulation ${ }^{1-7,} 19,30$}

Granulation is also known as agglomeration. Fluidized bed granulator (FBG), a highly economical and efficient one pot process, is a popular technique in the pharmaceutical industry for achieving particle size enlargement. Fluidized bed granulation technique recently, a method for preparation of solid dispersion using fluid bed granulation process. Solid dispersion using fluidized bed granulation process has been attracting attention as a manufacturing process because it overcomes so many drawbacks and problems arising in other multistep granulation and solid dispersion manufacturing processes. With the help of fluid bed granulator, we can perform several unit operations, such as preblending, drying and granulation and the granules produced in this process are processed by tableting process and filling in capsule shell. This is important for scale up. Manufacturing process steps get reduces in fluidized bed granulation therefore requires less manufacturing time. Handling of raw materials also reduced by the fluid bed granulation and drying, and therefore reduces operator exposure to toxic and irritating compounds. Fluidized bed granulation it is the critical 
process in which both process and product variables affects the various characteristics of the granules.

\section{Principle}

The fluid bed it is the bed of powder material or solid particle bed. The hot air passed at high pressure through the air distribution plate which is place in bottom then particles are lifted from bottom and suspended in air stream this process known as fluidization process. Fluid bed granulation process involves the spraying of binder solution, dispersion or suspension onto a physical mixture i.e. powder bed, where particles are suspended in air stream. These particles are wet by binder solution and when they collide to each other then formation of the liquid bridges and then dried which leads to acquisition of granules.

\section{Advantages}

$>$ To improve compressibility for tableting \& Continuous operation.

$>$ Applicable for large or small-scale operations \& saving labor cost.

$>$ Time and cost effective. Improve housekeeping and workers safety.

\section{Disadvantages}

$>$ Cleaning was labor intensive and time consuming

$>$ Due to the complexity of fluidized bed behavior, there are often difficulties in attempting to scale-up from smaller scale to industrial units

In present study we are going to Enhance solubility and dissolution rate of different formulations of Carvedilol by using Novel technique such as Fluidized bed granulation technique. We also focus on the formulate granules by using fluidized bed granulation technique (FBP - Top spraying). And to study the effect of process on dissolution efficiency of carvedilol. And other formulation related properties by applying suitable optimization techniques for the development of formulation using control strategies. Finally, we are going to compare the Optimized formulation of Carvedilol with marketed formulation.

\section{MATERIALS ${ }^{13,14,15,21,26}$}

Carvedilol obtained from IPCA Pharmaceuticals, PVP K30, poloxamer 188, citric acid, coloring agent, magnesium stearate, lactose, talc.

\section{Preformulation Study 21,27,28}

a) Organoleptic Properties - Color, odor, appearance

b) Solubility - Solubility was observed in various solvent

c) Melting point - Determined by using Thiele's tube technique.

\section{d) Ultraviolet visible (UV) spectroscopy ${ }^{21,27,28}$}

\section{Wavelength of maximum absorption ( $\Lambda$ max) determination}

Stock solutions $(100 \mu \mathrm{g} / \mathrm{ml})$ of Carvedilol were prepared in methanol. The UV spectrum was recorded in the range 200-400 $\mathrm{nm}$ by using UV spectrophotometer. The wavelength of maximum absorption ( $\lambda$ max) was determined.

\section{Preparation of Carvedilol standard stock solution $(100 \mu \mathrm{g} / \mathrm{ml})$ in Methanol}

A standard stock solution - Dissolving accurate weighed $10 \mathrm{mg}$ of Carvedilol in small quantity of methanol in $100 \mathrm{ml}$ of volumetric flask. The volume was then make up to $100 \mathrm{ml}$ using methanol to obtain a stock solution of $100 \mu \mathrm{g} / \mathrm{ml}$.

Standard calibration curve of Carvedilol in HCL pH 1.45 Accurately weighed $10 \mathrm{mg}$ of Carvedilol was dissolved in $100 \mathrm{ml}$ of Methanol to produce a $100 \mu \mathrm{g} / \mathrm{ml}$ concentration stock solution. The aliquots $2,4,6,8,10 \mathrm{ml}$ of stock solution pipette out into $10 \mathrm{ml}$ volumetric flask. The volume was made up to the mark with $\mathrm{HCL} \mathrm{pH} \mathrm{1.45.} \mathrm{This} \mathrm{dilution} \mathrm{gives}$ $20,40,60,80$ and $100 \mu \mathrm{g} / \mathrm{ml}$ concentration of Carvedilol respectively. Then all solutions were scanned at wavelength ( $\max 242 \mathrm{~nm}$ using UV spectrophotometer against the blank solution of $\mathrm{HCL}$ pH 1.45).

\section{Method of Preparation}

Table 1: Formulation code for each Batch

\begin{tabular}{|c|c|c|c|c|c|c|c|c|c|c|}
\hline Sr. No & Ingredients & F1 & F2 & F3 & F4 & F5 & F6 & F7 & F8 & F9 \\
\hline 1. & Carvedilol & $12.5 \mathrm{mg}$ & $12.5 \mathrm{mg}$ & $12.5 \mathrm{mg}$ & $12.5 \mathrm{mg}$ & $12.5 \mathrm{mg}$ & $12.5 \mathrm{mg}$ & $12.5 \mathrm{mg}$ & $12.5 \mathrm{mg}$ & $12.5 \mathrm{mg}$ \\
\hline 2. & PVP K30 & $10 \%$ & $15 \%$ & $12.5 \%$ & $10 \%$ & $12.5 \%$ & $15 \%$ & $12.5 \%$ & $10 \%$ & $15 \%$ \\
\hline 3. & Poloxamer 188 & $5 \%$ & $10 \%$ & $7.5 \%$ & $7.5 \%$ & $5 \%$ & $7.5 \%$ & $10 \%$ & $10 \%$ & $5 \%$ \\
\hline 4. & Citric Acid & $1 \mathrm{mg}$ & $1 \mathrm{mg}$ & $1 \mathrm{mg}$ & $1 \mathrm{mg}$ & $1 \mathrm{mg}$ & $1 \mathrm{mg}$ & $1 \mathrm{mg}$ & $1 \mathrm{mg}$ & $1 \mathrm{mg}$ \\
\hline 5. & Mg.Stearate & $2 \mathrm{mg}$ & $2 \mathrm{mg}$ & $2 \mathrm{mg}$ & $2 \mathrm{mg}$ & $2 \mathrm{mg}$ & $2 \mathrm{mg}$ & $2 \mathrm{mg}$ & $2 \mathrm{mg}$ & $2 \mathrm{mg}$ \\
\hline 6. & Talc & $4 \mathrm{mg}$ & $4 \mathrm{mg}$ & $4 \mathrm{mg}$ & $4 \mathrm{mg}$ & $4 \mathrm{mg}$ & $4 \mathrm{mg}$ & $4 \mathrm{mg}$ & $4 \mathrm{mg}$ & $4 \mathrm{mg}$ \\
\hline 7. & Color & q. s. & q. s. & q. s. & q. s. & q. s. & q. s. & q. s. & q. s. & q. s. \\
\hline 8. & Lactose & $\begin{array}{l}\text { Upto } \\
200 \mathrm{mg}\end{array}$ & $\begin{array}{l}\text { Upto } \\
200 \mathrm{mg}\end{array}$ & $\begin{array}{l}\text { Upto } \\
200 \mathrm{mg}\end{array}$ & $\begin{array}{l}\text { Upto } \\
200 \mathrm{mg}\end{array}$ & $\begin{array}{l}\text { Upto } \\
200 \mathrm{mg}\end{array}$ & $\begin{array}{l}\text { Upto } \\
200 \mathrm{mg}\end{array}$ & $\begin{array}{c}\text { Upto } 200 \\
\text { mg }\end{array}$ & $\begin{array}{l}\text { Upto } \\
200 \mathrm{mg}\end{array}$ & $\begin{array}{l}\text { Upto } \\
200 \mathrm{mg}\end{array}$ \\
\hline
\end{tabular}




\section{Method of Preparation}

Using a top spray technique in fluidized bed granulator solid dispersion granules was prepared. Polymer (PVP K30) and nonionic surfactant (Poloxamer 188) were dissolved in methanol. Then Carvedilol powder slowly added in solution and stirred for $5 \mathrm{~min}$ to obtained homogenous state. This resulting solution was sprayed under appropriate conditions i.e. Spray rate(1.50- 2 rpm), Atomizing air pressure(1.0-1.5 bar ), Product temperature $\left(40-500^{\circ} \mathrm{C}\right)$, Inlet temperature $\left(50-60^{\circ} \mathrm{C}\right)$, Fluidizing pressure (1.0-1.5 bar )on flowing mixture it contain citric acid, lactose, talc in fluidized bed granulator simultaneously fluidizing air passed and granules was dried. Granules were prepared accordingly to the amount which is described in formulation table. After the formation of granules in fluidized bed granulator an additional drying process was carried out for 15-20 min. for lubrication efficacy magnesium stearate was added in obtained solid dispersion granules and powder containing the solid dispersion granules was passed through a sieve and then compressed into tablets.

Evaluation 6,7, 8, 9, 10-25, 31, 32

\section{Pre-Compression evaluation}

\section{Bulk density}

Apparent bulk density was determined by pouring a weighed quantity of powder into graduated cylinder and measuring the volume of packing.

Bulk density = Weight of the powder / Volume of the packing

\section{Tapped density}

Tapped density was determined by tapping method. Weighed quantity of powder was placed in a graduated cylinder, after the initial volume was observed, and tapped until no further change in volume of powder was noted and the volume of tapped packing was noted.

Tapped density = weight of the powder / volume of the tapped packing

\section{Angle of repose $(\theta)$}

Angle of repose was determined by using fixed funnel method. Angle of repose is defined as the maximum angle possible between the surface of a pile of the powder and horizontal plane. The frictional force in a loose powder or granules can be measured by the angle of repose.

$$
\tan \theta=h / r \quad \text { or } \theta=\tan ^{-1}(h / r)
$$

Where, $\theta$ is the angle of repose, $h$, is height of pile, $r$ is radius of the base of the pile,

\section{Hausner's ratio}

Hausner's ratio is an indirect index of ease of power flow.

Hausner's ratio $\quad=\quad \frac{\text { Tapped density }}{\text { Bulk density }}$

\section{\% compressibility index}

(\%) Carr's Index can be calculated by using the following formula

Tapped density - bulk density

$$
\text { Car's consolidationindex } \%=\frac{}{\text { Tapped density }} \times 100
$$

\section{Post-Compression parameters}

\section{Hardness test}

The hardness of the tablets was determined using Digital Hardness tester. It is expressed in $\mathrm{Kg} / \mathrm{cm}^{2}$. Three tablets were randomly picked from each formulation and the mean and standard deviation values were calculated.

\section{Friability test}

The friability of tablets was determined by using Electro lab, USP EF 2 friabilator. It is expressed in percentage (\%). Ten tablets were initially weighed $\left(I_{\text {nitial }}\right)$ and transferred into friabilator. The friabilator was operated at 25 RPM for 4 minutes. The tablets were weighed again $\left(F_{\text {inal }}\right)$.

$$
F=\frac{W_{\text {initial }}-W_{\text {final }}}{W_{\text {initial }}} \times 100
$$

$\%$ Friability of tablets less than $1 \%$ is considered acceptable.

\section{Weight variation test}

The tablets were selected randomly from each formulation and weighed individually to check for weight variation. The U.S Pharmacopoeia allows a little variation in the weight of a tablet. The following percentage deviation in weight variation is allowed. Average weight of a tablet -200mg or less their \% deviation was $10 \%$; More than $190 \mathrm{mg}$ and less than $200 \mathrm{mg}$ - \% Deviation was $7.5 \%$; or more average weight tablet than $200 \mathrm{mg}$ - and 5 their \% deviation was 5 $\%$.

\section{Uniformity of thickness}

The thickness of individual tablet may be measured with a digital vernier calliper, which permits accurate measurements and provides information on the variation between tablets.

\section{Drug content 21}

Weighed tablets (5) were powdered using glass mortar and pestle. Accurately weighed quantity of powder equivalent to $12.5 \mathrm{mg}$ of carvedilol was taken into $50 \mathrm{ml}$ volumetric flask dissolved in methanol and the solution was filtered through whatmann filter paper. The filtrate was collected and suitably diluted with methanol to volume to prepare a solution having a known concentration of about $0.125 \mathrm{mg}$ per $\mathrm{mL}$. The drug content was determined at $241 \mathrm{~nm}$ by UV- Spectrophotometer should compare with that of a reference standard solution similarly prepared. 


\section{Disintegration time}

The disintegration time of the tablets was determined as per Indian pharmacopoeia. The test was carried out using tablet disintegration apparatus. $900 \mathrm{ml}$ Distilled water was used as a disintegrating media at $37 \pm 0.2{ }^{\circ} \mathrm{C}$. The time required to obtain complete disintegration of all the tablets were noted.

\section{In vitro drug release ${ }^{21}$}

In vitro Release of the drug was determined by estimating the dissolution profile, USP II Paddle apparatus was used and paddle was allowed to rotate at $50 \mathrm{rpm}$, Hydrochloric acid adjusted to $\mathrm{pH}$ of 1.45 , $(900 \mathrm{ml}$ ) was used as a dissolution medium. Temperature of dissolution medium was $37 \pm 0.5^{\circ} \mathrm{C} 5 \mathrm{ml}$ samples were withdrawn at predetermined intervals upto $30 \mathrm{~min}$ and replacements were done with fresh dissolution medium. The samples were suitably diluted and analyzed for drug content Absorbance measured at $242 \mathrm{~nm}$ by UV spectroscopy.

\section{Comparative Study With Marketed Preparation}

In this test comparison of different parameters of formulation like weight, color, shape, weight variation, friability, hardness, diameter, drug content, Disintegration time and \% CDR. This all are the parameters will compared with Marketed formulation.

\section{Saturation Solubility}

Preparing saturated solution of pure drug and its granules by using FBG Technique in constant volume of distilled water, acidic buffer ( $\mathrm{pH}$ 1.45). These mixtures were stirred in a mechanical shaker for $24 \mathrm{Hrs}$ at room temperature. Visual inspection was carefully made to ensure there were excess particles in the mixture, indicating saturation has been reached. Aliquots from each sample were filtered through $0.45 \mu \mathrm{m}$ whatman filter paper and filtrate was diluted suitably to determine the saturation solubility of samples. Drug solubility was evaluated spectrophotometrically using UV visible spectrometer at $242 \mathrm{~nm}$ using respective medium as a reference. Saturation solubility measurements were performed in triplicate.

\section{Stability Studies ${ }^{29}$}

The purpose of stability testing is to provide evidence on how the quality of a drug substance or drug product varies with time under the influence of a variety of environmental factors such as temperature, humidity and light. The ability of a pharmaceutical product to retain its chemical, physical, microbiological and biopharmaceutical properties within specified limits throughout its shelf life and recommended storage conditions.

\section{RESULTS AND DISCUSSION}

\section{Preformulation study}

Identification and Characterization of drug

Organoleptic properties
Carvedilol has white color, Odorless, Crystalline powder. Hence, the all characteristics of drug are complies as per I.P. 2014 therefore it's confirmed that the model drug has good properties.

\section{Melting point}

The melting point was determine by capillary method and it was found to be $116-117^{\circ} \mathrm{C}$ (observed value) and $114-115$ ${ }^{0} \mathrm{C}$ (standard value). I.e. the melting point of Carvedilol was complies with I.P. 2014

\section{Solubility}

The solubility of Carvedilol was checked in different solvents like Methanol (Freely soluble), Chloroform (soluble), Ethanol (Sparingly Soluble), Water (insoluble) etc.

\section{UV-Spectrum of Carvedilol ${ }^{23,} 24$}

\section{Determination of $\lambda$ max of Carvedilol in Methanol}

The Ultra-violet spectroscopic absorbance of Carvedilol was done in Methanol at the $242^{\circ}$ max.

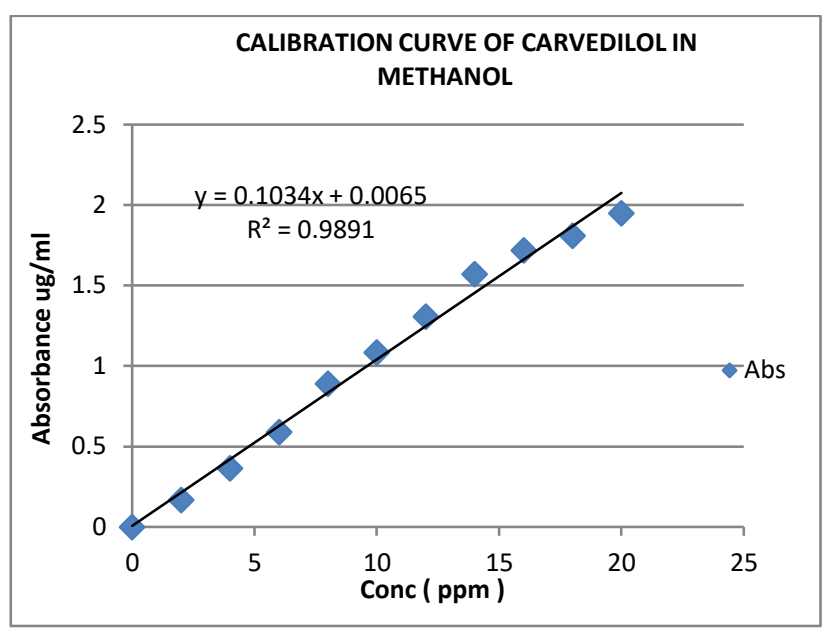

The equation of the regression line was obtained $Y=0.103 X+0.006$ and the correlation coefficient was obtained 0.989. The calibration curve yields a straight line, which shows that the drug follows Beer's law in the concentration range 2 to $20 \mu \mathrm{g} / \mathrm{ml}$.

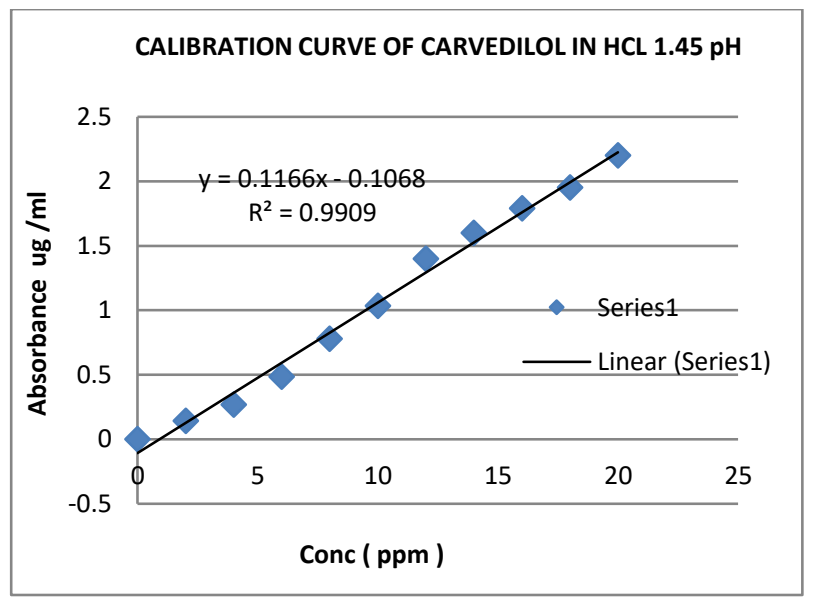

Figure 1: Calibration curve of Carvedilol in a) Methanol b) HCL pH 1.45 
The equation of the regression line was obtained $\mathrm{Y}=0.116 \mathrm{X}-0.106$ and the correlation coefficient was obtained 0.990 .

\section{Evaluation of Final Batches}

Table 2: Pre-compression evaluations of formulations

\begin{tabular}{|c|c|c|c|c|c|c|}
\hline Sr. No. & Formulation Code & $\begin{array}{l}\text { Bulk Density } \\
(\mu \mathrm{g} / \mathrm{ml})\end{array}$ & $\begin{array}{l}\text { Tapped Density } \\
(\mu \mathrm{g} / \mathrm{ml})\end{array}$ & $\begin{array}{c}\text { Carr's Index } \\
\text { (\%) }\end{array}$ & Hausner's Ratio & Angle of Repose $\left({ }^{\circ}\right)$ \\
\hline 1 & F1 & 0.48 & 0.602 & 20 & 1.25 & 26.29 \\
\hline 2 & F2 & 0.4 & 0.5 & 20 & 1.25 & 27.02 \\
\hline 3 & F3 & 0.254 & 0.31 & 18.06 & 1.22 & 25.3 \\
\hline 4 & F4 & 0.62 & 0.78 & 20.5 & 1.25 & 28.41 \\
\hline 5 & F5 & 0.385 & 0.394 & 15 & 1.19 & 28.2 \\
\hline 6 & F6 & 0.345 & 0.399 & 13.53 & 1.15 & 24.21 \\
\hline 7 & F7 & 0.278 & 0.452 & 16.3 & 1.6 & 26.32 \\
\hline 8 & F8 & 0.258 & 0.324 & 20.3 & 1.27 & 25.48 \\
\hline 9 & F9 & 0.61 & 0.72 & 15.49 & 1.18 & 26.32 \\
\hline
\end{tabular}

\section{DISCUSSION}

The bulk density, tapped density, Angle of repose, Carr's index and Hausner's ratio obtained for all the formulations which is in the good or in the acceptable range and All these results indicated that, the powder mixture possess good flow of powder and compressibility properties.

Table 3: Post-compression evaluation of formulations

\begin{tabular}{|c|c|c|c|c|c|c|c|c|}
\hline Sr. No. & $\begin{array}{c}\text { Formulation } \\
\text { Code }\end{array}$ & $\begin{array}{c}\text { Weight } \\
\text { Variation }(\mathrm{mg})\end{array}$ & $\begin{array}{l}\text { Diameter } \\
(\mathrm{mm})\end{array}$ & $\begin{array}{l}\text { Thickness } \\
(\mathrm{mm})\end{array}$ & $\begin{array}{l}\text { Hardness } \\
\left(\mathrm{Kg} / \mathrm{cm}^{2}\right)\end{array}$ & Friability (\%) & $\begin{array}{c}\text { D.T. } \\
\text { (min/sec) }\end{array}$ & $\begin{array}{c}\text { Drug } \\
\text { Content (\%) }\end{array}$ \\
\hline 1 & $\mathrm{~F} 1$ & 198 & 8 & 3.61 & 4.35 & 0.81 & 2 & 89.76 \\
\hline 2 & F2 & 200 & 8 & 3.64 & 4.2 & 0.83 & 2.1 & 87.67 \\
\hline 3 & F3 & 195 & 8 & 3.68 & 4.28 & 0.92 & 2.2 & 92.76 \\
\hline 4 & F4 & 198 & 8 & 3.63 & 4.3 & 0.9 & 1.5 & 93.56 \\
\hline 5 & F5 & 197 & 8 & 3.7 & 4.27 & 0.98 & 1.5 & 91.22 \\
\hline 6 & F6 & 199 & 8 & 3.68 & 4.37 & 0.95 & 1 & 98.7 \\
\hline 7 & F7 & 197 & 8 & 3.72 & 4.3 & 0.92 & 2 & 88.78 \\
\hline 8 & F8 & 198 & 8 & 3.68 & 4.24 & 0.94 & 2.5 & 91.31 \\
\hline 9 & F9 & 192 & 8 & 3.62 & 4.2 & 0.91 & 1.7 & 94.42 \\
\hline
\end{tabular}

\section{Discussion}

The weight variation, diameter, Thickness, Hardness, friability, and Disintegration time obtained for all the formulations in the range which is in the good or in the acceptable range.

\section{Dissolution Study of Final Batches:}

Table 4: In-vitro dissolution study of Different formulation

\begin{tabular}{|c|c|c|c|c|c|c|c|c|c|}
\hline Time (min) & F1 & F2 & F3 & F4 & F5 & F6 & F7 & F8 & F9 \\
\hline 0 & 0 & 0 & 0 & 0 & 0 & 0 & 0 & 0 & 0 \\
\hline 5 & 19.73 & 20.11 & 22.13 & 20.67 & 25.71 & 30.16 & 28.14 & 25.20 & 28.41 \\
\hline 10 & 25.67 & 28.19 & 30.68 & 35.10 & 40.22 & 48.71 & 31.67 & 38.41 & 42.10 \\
\hline 15 & 38.18 & 41.67 & 42.20 & 45.91 & 48.67 & 55.10 & 40.78 & 43.67 & 49.89 \\
\hline 20 & 47.61 & 48.16 & 46.87 & 49.28 & 66.17 & 73.24 & 64.23 & 60.79 & 70.22 \\
\hline 25 & 56.98 & 57.88 & 58.12 & 65.38 & 75.12 & 85.82 & 70.88 & 66.23 & 81.12 \\
\hline 30 & 66.53 & 68.21 & 68.89 & 72.88 & 80.45 & 95.18 & 76.42 & 75.61 & 81.66 \\
\hline
\end{tabular}




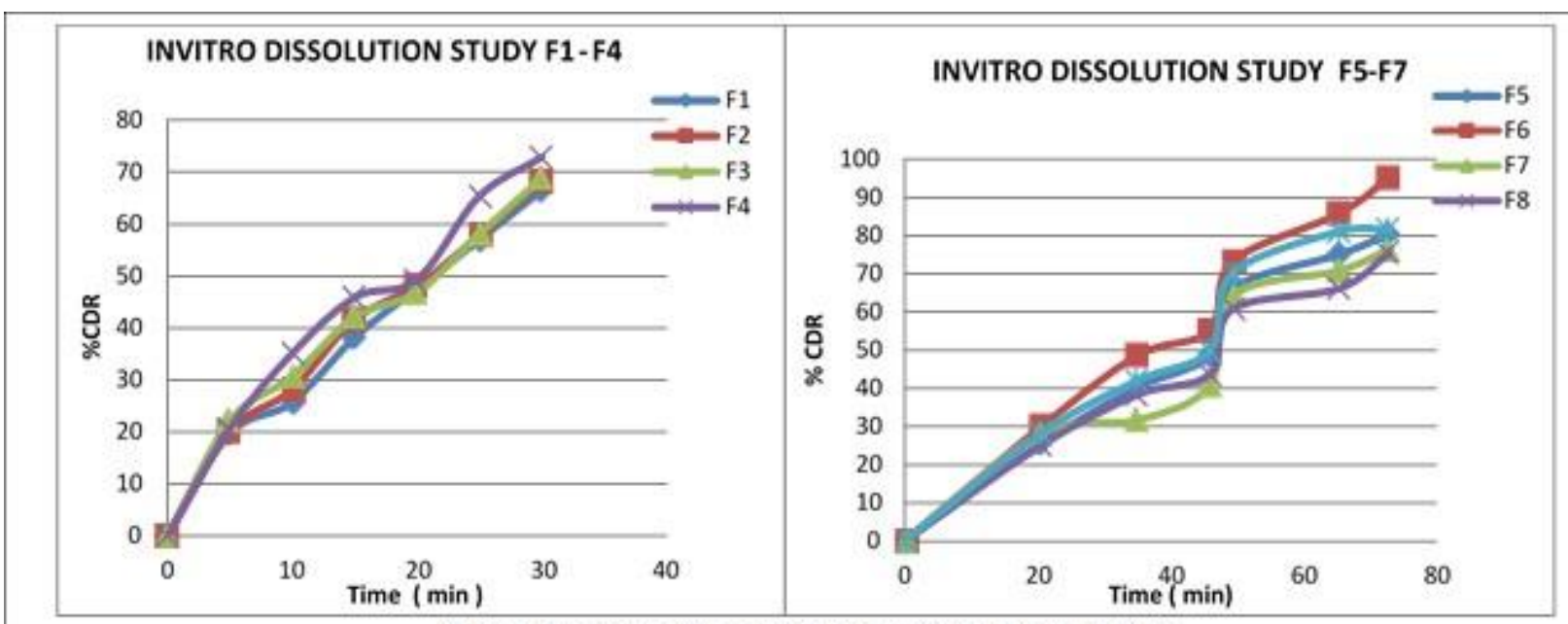

Figu re 2: In-Vitro dissolution study of F1-F9 formulation

Formulation F6 shown best appropriate drug release rate.

Comparison of in-vitro dissolution study of pure drug (carvedilol), marketed formulation and optimized formulation.

Table 5: In-Vitro Dissolution Comparative Study

\begin{tabular}{|c|c|c|c|}
\hline Time(min) & PURE DRUG (P.D) & MARKETED PRODUCT (M.P) & OPTIMIZED PRODUCT (F6) (O.P.) \\
\hline 0 & 0 & 0 & 0 \\
\hline 5 & 8.21 & 50.21 & 35.16 \\
\hline 10 & 9.78 & 59.43 & 48.71 \\
\hline 20 & 12.53 & 69.12 & 65.1 \\
\hline 25 & 16.05 & 80.15 & 78.24 \\
\hline 30 & 20.61 & 88.83 & 85.89 \\
\hline
\end{tabular}

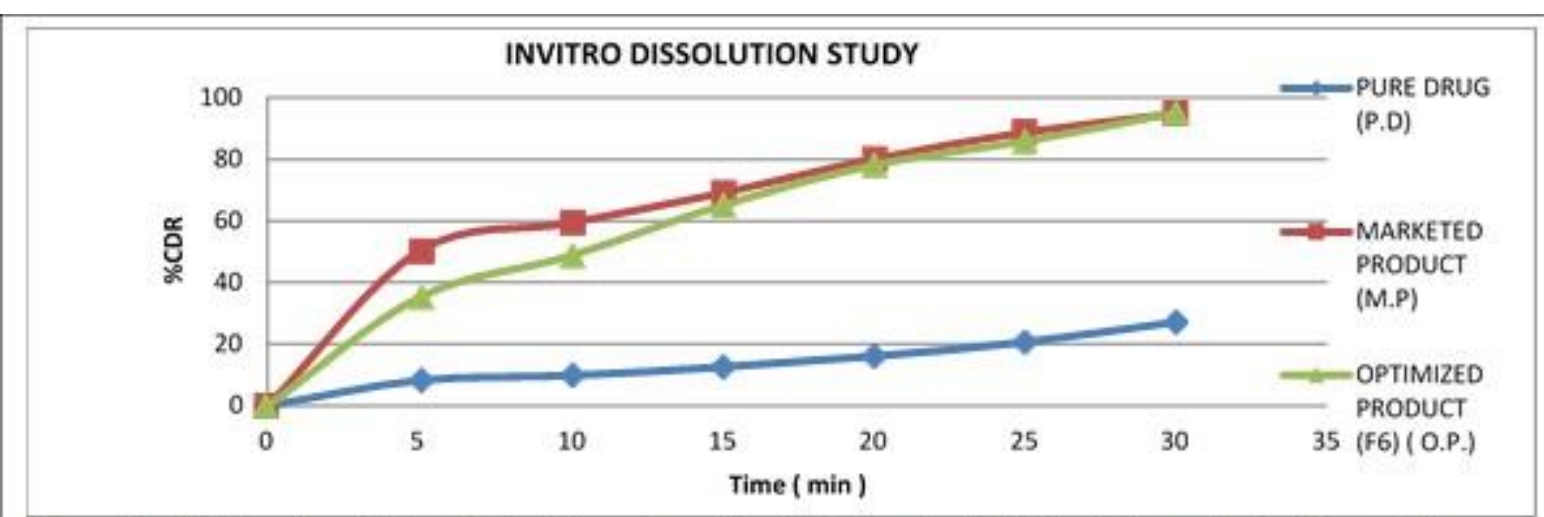

Figure 3: In-Vitro dissolution study of Pure drug, Marketed product, Optimized product formulations

\section{Saturation Solubility}

The saturation solubility study of pure drug and prepared granules in different physiological mediums. The results of solubility study indicated that Carvedilol granules possess a very high solubility in all physiological medium than pure

\section{Comparative Study (Marketed preparation)}

\section{Stability Study}

There was no physical change in color. There is no any significant change in the weight variation, drug content, $\% C D R$, and friability of tablets in comparison with the drug. The saturation solubility of Carvedilol pure drug in distilled water and $\mathrm{HCL} \mathrm{pH} 1.45$ medium was found to be $8.58 \mathrm{ug} / \mathrm{ml}$ and $7.98 \mathrm{ug} / \mathrm{ml}$. And the saturation solubility of Carvedilol granules in distilled water and $\mathrm{HCL} \mathrm{pH} 1.45$ medium was found to be $21.49 \mathrm{ug} / \mathrm{ml}$ and $130 \mathrm{ug} / \mathrm{ml}$.

initial samples of optimized batch. This formulation stable at 2 months. 
Table 6: Comparative study of optimized formulation with marketed formulation

\begin{tabular}{|c|c|c|}
\hline Test & $\begin{array}{c}\text { Optimized } \\
\text { formulation }\end{array}$ & Marketed formulation \\
\hline Weight & $200 \mathrm{mg}$. & $200 \mathrm{mg}$. \\
\hline $\begin{array}{c}\text { Color } \\
\text { Shape } \\
\text { Weight } \\
\text { variation }\end{array}$ & $\begin{array}{c}\text { Orange } \\
\text { Rounded }\end{array}$ & $\begin{array}{c}\text { Yellow } \\
\text { Rounded }\end{array}$ \\
\hline Friability & $199 \mathrm{mg}$. & $199 \mathrm{mg}$ \\
\hline Hardness & $4.37 \mathrm{~kg} / \mathrm{cm}{ }^{2}$ & $5.012 \mathrm{~kg} / \mathrm{cm}^{2}$ \\
\hline Diameter & $8 \mathrm{~mm}$. & $8 \mathrm{~mm}$. \\
\hline $\begin{array}{c}\text { Drug content } \\
\text { Disintegration } \\
\text { time }\end{array}$ & $98.70 \%$ & $99.69 \%$ \\
\hline$\%$ CDR & $95.18 \%$ & $51.20 \mathrm{sec}$ \\
\hline
\end{tabular}

\section{CONCLUSION}

This study demonstrate that the method, Fluidized Bed Granulation technique is suitable for the Enhancement of Solubility and Dissolution rate of Carvedilol drug by using various hydrophilic and hydrophobic polymers for in-vitro studies of Carvedilol Tablet. Different polymers like PVP K30 and Poloxamer 188. However, the granules produced by FBG technique it showed good flowability and other parameters, indicating that this technique seems to be the best alternative for large production of solid dosage forms. The formulation F6 showed Enhance Solubility and Dissolution rate of carvedilol drug released approximately $95.18 \%$ for $30 \mathrm{~min}$. So it was selected as the best formulation among all the nine formulations.

Acknowledgment: The author is thankful to IPCA pharmaceuticals India and also thankful to Mr. Harish Kale for providing gift sample of carvedilol. Author is delighted to say thank you to Loknete Dr. J.D. Pawar college of Pharmacy, Manur, (Kalwan), For support and providing necessary facilities to carry out my research work successfully.

\section{REFERENCES}

1. Sharma K, Ahuja N, Soni P, Ahlawat S, Chaudhary H, Garg A, Fluidized bed granulation: A Novel strategy for Development of low Dose formulation, journal of pharmacy Research, 5(11),2012,4991-4997.

2. Gohel M, Parikh R, Popat A, Mohapatra A, Barot B, Patel C, Joshi $\mathrm{H}$, Sarvaiya K, Baldaniya L, Mistry P, Parejiya P, Parmar $R$, Nagori $S$, Patel T, Fluidized bed system : A Review, Pharmainfo.net, 2007.

3. Yadhav CS, Lariya N, Fluid bed Granulation: Basics, Process Variables and Technology upgradation, Journal of Pharma Research , 5 (10), 2016, 224-228.

4. Srivastava S, Mishra G, Fluid bed Technology : Overview and Parameters for Process Selection, International Journal of Pharmaceutical science and Drug research, 2(4), 2010, 236246.
5. Hyeok Jin Kwon, Eun-Ji Heo, Young-Hwan Kim, Sarah Kim, Young-Ha Hwang,

Ji-Mi Byun, Se Hyeop Cheon, Sang Yeob Park, Dong Yun Kim, Kwan Hyung Cho,Han-Joo Maeng , and Dong-Jin Jang, Development and Evaluation of Poorly Water-Soluble Celecoxib as Solid Dispersions Containing Nonionic Surfactants Using Fluidized-Bed Granulation Pharmaceutics 2019, 11, 136, 1-13.

6. Raj A, Harindran J, formulation and evaluation of carvedilol solid Dispersion tablets for solubility enhancement, European journal of biomedical and pharmaceutical sciences, 4 (2), 2017, 334- 348.

7. Ellen C.P. Alonso, Karina Riccomini, Luis Antonio D. Silva et.al., Development of carvedilol- cyclodextrin inclusion complexes using fluid-bed granulation: a novel solid-state complexation alternative with technology advantages, Journal of pharmacy and Pharmacology, 2016, 1-11.

8. Aulton ME, "Granulation", Pharmaceutics, The Science of dosage form design, Second Edition, Churchill Livingstone, Edingburgh, 2002, 373.

9. Andrea Ikeda Takahashi, Feliperebello lourenco, Marcelo dutra duque, Vladioga consiglieri, Humberto gomes ferraz, Fluid bed granulation to improve the dissolution of poorly water-soluble drugs, Brazilian Archives of Biology and Technology, 55 (3), 2012, 477-484.

10. Srinivasa Rao Y, Vijaya L, Varalakshmi TSNS, Chandana R, Chowdary KPR, Formulation and Evaluation of Carvedilol Solid Dispersions for Dissolution Rate Enhancement, International Journal of Advances in Pharmacy, Biology and Chemistry, 1(4), 2012, 489- 495.

11. Hossain Md.Shafayat, Hossain Md. Anwar, Anissuzzman Md, Formulation Development and Evaluation of carvedilol tablet, International Research journal of Pharmacy, 4( 8), 2013, 96100.

12. Tapas A, Kawtikwar P, Sakarkar D, An important in physicochemical properties of carvedilol through spherically agglomerated solid dispersion with PVP K30, Acta Poloniae Pharmaceutica n Drug Research, 69( 2), 2012, 299-308.

13. https:// www.drugbank.ca/drugs/DB01136.

14. https://www.medlineplus,gov/druginfo/meds/a697042.html

15. https://en.wikipedia.org/wiki/carvedilol.

16. Lachman L, Lieberman HA, Kanig JL, "Granulation", The Theory and practice of Industrial pharmacy, Third Edition, Verghese Publishing House, Bombay, 1991,58-59.

17. Ansel C, Allen LV, Popovich NG," Tablets", Pharmaceutical dosage form and drug delivery system, eighth edition, B.I. Publications, India, 2005, 193 \& 243.

18. Dewan I., Hossain A, Islam ASM, Formulation and Evaluation of solid dispersions of carvedilol, a poorly water-soluble drug by using different polymers, International journal of research in pharmacy and chemistry,2 (3), 2012, 585- 593.

19. Shouichi Hosaka, Yasufumi Okamura, Yuji Tokunaga, Preparation of fine particles with improved solubility using a complex fluidized bed granulator equipped with a particle sizing mechanism ,Chem. Pharma Bull, 64 (6), 2016, 644-649. 
20. Bhavsar MR, Savkare AD, Enahncement of aqueous solubility of carvedilol by liquisolid technique, Indo American Journal of Pharmaceutical Research, 7(08), 2017, 537-549.

21. 2011 USP 34 Nf 29, U.S. Pharmacopeia, National Formulary Voume-1, Pharmacopeial Convention 12601 twin brook Parkway, Rockville M. D. 20852, Page No. 2189-2193.

22. Amna MA Makky, Iman S. Ahmed, Mohmed A, EL-Nabarawi, Raheb A. Abd EL-Moneim, Development of a new carvedilol tablet with rapid onset of action, American journal of drug discovery and development , 2 (2), 2012, 55-71

23. Ayoub M, Hasan A, Hanan EL Nahas, Fakhr-Eldin Ghazy, Enhancing oral bioavailability of carvedilol using solid dispersion technique, International Journal of Pharmacy and Pharmaceutical Sciences,8 (7),2016, 193-199.

24. Kumar VU, Naik VV, Rao NY, Reddy N, Chowdary KPR, formulation and evaluation of modified release carvedilol tablets, An International Journal of Advances In Pharmaceutical Sciences, 1 (1), 2010, 83-87.

25. Ratnam SV, Bhowmik D, Yadav D, formulation and evaluation of carvedilol fast dissolving tablets, Journal of Chemical and Pharmaceutical Sciences, 7(2), 2014, 85-88.
26. Raymond C. Row, Paul J. Sheskey and Marian E. Quinn, Handbook of Pharmaceutical Excipients, Sixth Edition, Page No.185-187, 430-433,385-388,535-538, 611-616,767-769.

27. Sharma Y. R, Elementary Organic Spectroscopy, Principles And Chemical Applications, S. Chand Publication; Reprint 2016, Page No 69-153.

28. Chatwal G. R, Anand S. K, Instrumental Methods of Chemical Analysis. $5^{\text {th }}$ Edition, Himalaya Publishing House; Reprint 2009, Page No. 2.49-2.51

29. Caretensen J.T, Guidelines for Drug Stability: Principles and Practices, Third Edition, Marcel Dekker. (2005), Page No. 252255.

30. Instruction Manual Mini Quest-F, Loknete Dr. J.D. Pawar College of Pharmacy, Manur (Nashik), Batch No.-MF 005, Sr. No.- M005F.

31. V. Ramesh, Jat RK, Chowdary K. P. R, Formulation of carvedilol tablets employing solid dispersion in MCC 102 and Poloxamer 188 as per $2^{2}$ factorial design , World Journal of Pharmacy and Pharmaceutical Sciences, 5( 2), 2016. 753-762.

32. Shinkar DM, Dhake AS, Setty CM, Solubility and Dissolution Enhancement of Carvedilol by Solid Dispersion Technique Using Gelucire 50/13, Int. J. Pharm. Sci. Rev. Res., 29(1), 2014, 161-165.

Source of Support: None declared.

Conflict of Interest: None declared.

For any question relates to this article, please reach us at: editor@globalresearchonline.net New manuscripts for publication can be submitted at: submit@globalresearchonline.net and submit_ijpsrr@rediffmail.com 